\title{
PENYAKIT MENULAR
}

\section{PENJASORKES}

SMAN 3 MEDAN

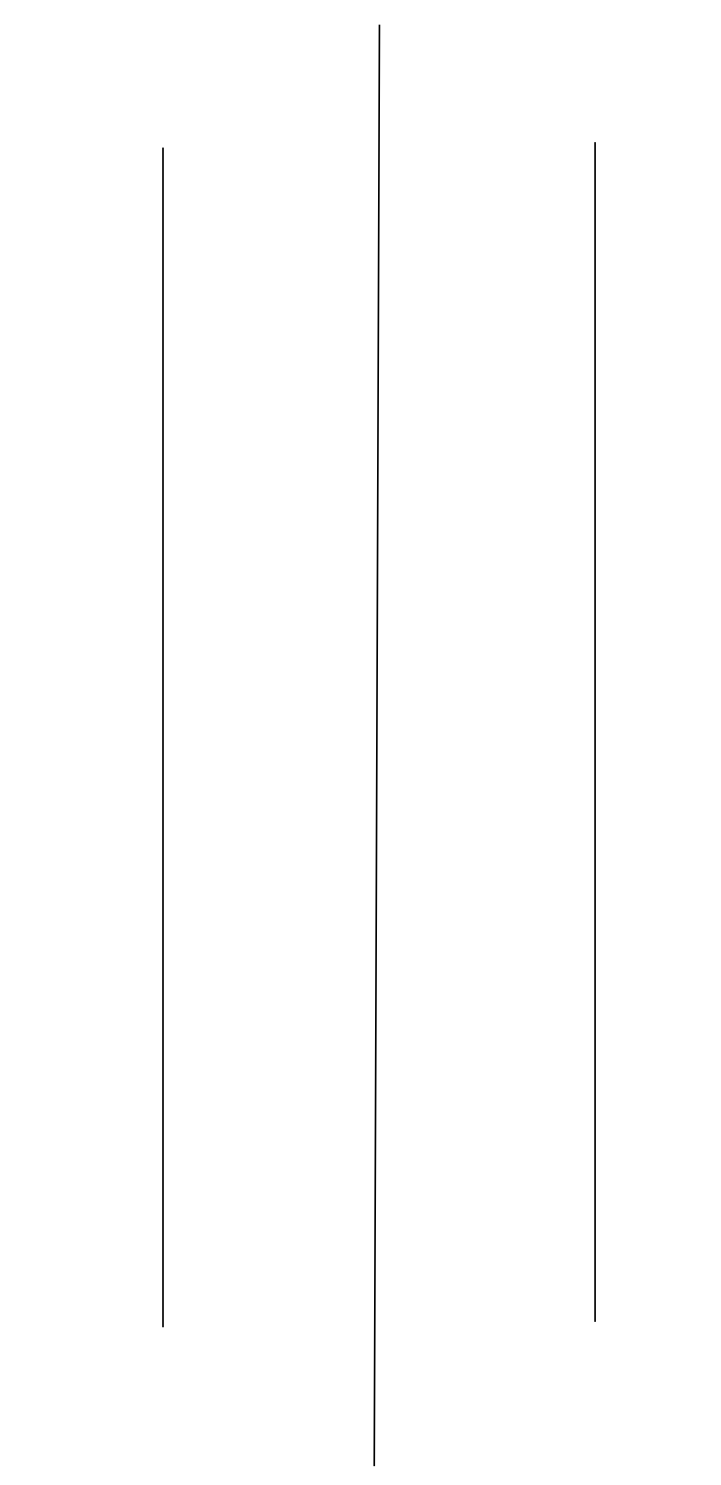

AMATUL SYAFIRA DAMANIK

X MIA 3 


\section{KATA PENGANTAR}

Puji syukur kehadirat Allah SWT yang telah memberikan rahmat dan hidayah-Nya sehingga saya dapat menyelesaikan tugas makalah yang berjudul PENYAKIT MENULAR ini tepat pada waktunya.

Adapun tujuan dari penulisan dari makalah ini adalah untuk memenuhi tugas guru pada bidang studi penjasorkes. Selain itu, makalah ini juga bertujuan untuk menambah wawasan tentang penyakit menular bagi para pembaca dan juga bagi penulis.

Saya mengucapkan terima kasih kepada bapak guru, selaku guru bidang studi PJOK yang telah memberikan tugas ini sehingga dapat menambah pengetahuan dan wawasan sesuai dengan bidang studi yang saya tekuni.

Saya juga mengucapkan terima kasih kepada semua pihak yang telah membagi sebagian pengetahuannya sehingga saya dapat menyelesaikan makalah ini.

Saya menyadari, makalah yang saya tulis ini masih jauh dari kata sempurna. Oleh karena itu, kritik dan saran yang membangun akan saya nantikan demi kesempurnaan makalah ini.

Medan, 8 Mei 2020

Penulis 


\section{DAFTAR ISI}

BAB 1 : PENDAHULUAN

a. Latar Belakang................................................

b. Rumusan Masalah...................................................2

c. Tujuan Masalah...............................................2

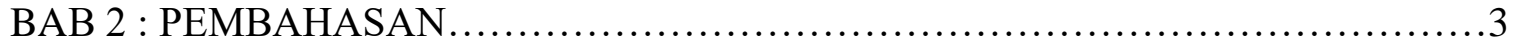

BAB 3 : KESIMPULAN.................................................20

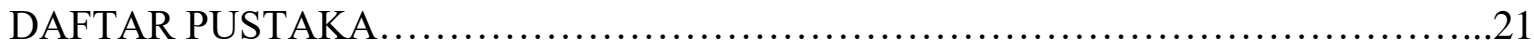




\section{BAB 1}

\section{PENDAHULUAN}

\section{A. Latar Belakang}

Penyakit menular merupakan penyakit infeksi yang disebabkan oleh mikroorganisme, seperti virus, bakteri, parasit, atau jamur, dan dapat berpindah ke orang lain yang sehat. Beberapa penyakit menular yang umum di Indonesia dapat dicegah melalui pemberian vaksinasi serta pola hidup bersih dan sehat.

Penyakit menular dapat ditularkan secara langsung maupun tidak langsung. Penularan secara langsung terjadi ketika kuman pada orang yang sakit berpindah melalui kontak fisik, misalnya lewat sentuhan dan ciuman, melalui udara saat bersin dan batuk, atau melalui kontak dengan cairan tubuh seperti urine dan darah. Orang yang menularkannya bisa saja tidak memperlihatkan gejala dan tidak tampak seperti orang sakit, apabila dia hanya sebagai pembawa (carrier) penyakit.

Selain metode penyebaran di atas, penyakit menular juga dapat menyebar melalui gigitan hewan, atau kontak fisik dengan cairan tubuh hewan, serta melalui makanan dan minuman yang terkontaminasi mikroorganisme penyebab penyakit.

Penyakit menular juga dapat berpindah secara tidak langsung. Misalnya saat menyentuh kenop pintu, keran air, atau tiang besi pegangan di kereta yang terkontaminasi. Kuman dapat menginfeksi jika Anda menyentuh mata, hidung, atau mulut tanpa mencuci tangan terlebih dahulu setelah menyentuh barang-barang tersebut.

Penyakit menular umumnya lebih berisiko mengenai orang yang memiliki daya tahan tubuh lemah dan tinggal di lingkungan dengan kondisi kebersihan yang kurang baik. Penyakit menular juga dapat meningkat pada waktu tertentu, misalnya pada musim hujan atau banjir . Gejala dan tanda penyakit penyakit menular tergantung pada jenis mikroorganisme yang menyebabkan penyakit infeksi. Di Indonesia, penyakit menular yang umumnya terjadi antara lain, yaitu ISPA, diare, tuberculosis, DBD, cacingan, penyakit kulit, malaria, dan difteri. 
Dahulu, polio termasuk ke dalam penyakit menular yang umum di Indonesia. Namun sejak tahun 2014, Indonesia telah dinyatakan bebas polio. Selain polio, penyakit tetanus dan cacar juga berhasil ditekan kasusnya sehingga tidak lagi dianggap sebagai masalah kesehatan yang besar. Hal ini merupakan keberhasilan yang didapatkan dari imunisasi yang diberikan secara nasional. Beberapa penyakit menular seperti flu, polio, hepatitis B, campak, cacar, difteri, dan TB memang dapat dicegah dengan pemberian vaksin.

Pencegahan penyakit menular juga bisa diupayakan melalui kebiasaan hidup sehat. Di antaranya tidak meludah sembarangan, mencuci tangan, tidak memakai peralatan pribadi bersamaan dengan orang lain, serta mengonsumsi makanan sehat dan bergizi untuk meningkatkan daya tahan tubuh terhadap penyakit.

\section{B. Rumusan Masalah}

1. Apa itu penyakit menular?

2. Bagaimana kemunculannya?

3. Apa saja contoh - contohnya ?

4. Bagaimana cara mencegahnya?

5. Apa itu COVID19?

6. Bagaimana awal mula menyebarnya virus ini?

\section{Tujuan Masalah}

1. Untuk memenuhi tugas mata pelajaran dari guru

2. Memperluas pemahaman tentang penyakit menular

3. Pengetahuan tentang COVID 19 


\section{BAB 2}

\section{PEMBAHASAN}

\section{A. PENYAKIT MENULAR}

Definisi penyakit menular adalah gangguan yang disebabkan oleh organisme seperti bakteri, virus, jamur, atau parasit. Disamping itu juga ada banyak organisme yang ada di dalam tubuh yang bersifat membantu kekebalan tubuh, namun dalam kondisi tertentu, beberapa organisme menyebabkan penyakit.

Dilansir dari Encyclopaedia Britannica, beberapa penyakit menular dapat ditularkan dari orang ke oranga. Beberapa juga bisa ditularkan oleh serangga atau hewan lainnya.

Penyakit menular disebabkan oleh agen biologi seperti mikroorganisme pategonik (virus, bakteri, dan fungi) serta parasit. Keberadaan mereka ada di dalam atau permukaan tubuh, sehingga dapat menyebabkan infeksi.

Perpindahan agen infeksi atau parasit tersebut dari individu yang sakit ke individu sehat dinamakan penularan penyakit. Jika seseorang terkena suatu bakteri atau terinfeksi namun kesehatan dalam tubuh tidak berubah maka proses ini disebut infeksi subklinis.

Prinsip tersebut diilustrasikan dengan penggunaan vaksin untuk pencegahan penyakit menular. Misalnya, virus yang menyebabkan campak dapat dilemahkan atau digunakan sebagai agen imunisasi.

\section{B. KELOMPOK PENYAKIT MENULAR}

Penyakit menular yang disebabkan oleh suatu agen infeksi atau produk racun dari orang maupun hewan bisa terjadi baik secara langsung maupun tidak langsung. Terdapat tiga kelompok utama penyakit menular, yaitu:

1. Penyakit sangat berbahaya karena angka kematian cukup tinggi 
2. Penyakit menular tertentu yang menimbulkan kematian dan cacat, walaupun akibatnya lebih ringan dari yang pertama.

3. Penyakit menular yang jarang menimbulkan kematian dan cacat tetapi dapat mewabah yang menimbulkan kerugian materi dan kesehatan

\section{KEMUNCULAN}

.Menurut ilmu epidemiologi, suatu penyakit dapat muncul akibat interaksi antara tiga unsur: agen, inang, dan lingkungan. Ketiganya merupakan unsur yang ada dalam segitiga epidemiologi. Interaksi antara agen penyebab dan inang dalam lingkungan yang mendukung akan menimbulkan penyakit.

\section{Agen}

Mikroorganisme patogen, parasit, maupun zat yang dihasilkannya (misalnya toksin) dapat menyebabkan penyakit. Berbagai faktor dapat memengaruhi apakah paparan terhadap agen dapat menimbulkan penyakit, misalnya jumlah agen infeksi dan patogenisitas (kemampuan agen infeksi untuk menimbulkan penyakit).

\section{Inang}

Individu yang menderita penyakit disebut inang. Faktor-faktor dalam diri inang yang berpengaruh terhadap kemungkinan timbulnya penyakit disebut faktor risiko, misalnya jenis kelamin, usia, kekebalan tubuh, dan perilaku.

\section{Lingkungan}

Faktor eksternal yang memengaruhi interaksi antara agen dan inang disebut lingkungan. Contohnya adalah iklim, kepadatan populasi, keberadaan vektor, dan sanitasi.

\section{RANTAI INFEKSI}


Suatu agen penyakit berpindah-pindah dari suatu tempat ke tempat lain dalam suatu rantai infeksi atau siklus infeksi. Rantai infeksi diawali dengan bermigrasinya agen penyakit dari reservoir melalui "portal keluar", lalu berpindah dengan cara penularan tertentu, dan melintasi "portal masuk" yang sesuai untuk menginfeksi inang yang rentan. ${ }^{[2]}$

\section{Reservoir}

Reservoir merupakan habitat atau tempat hidup, tumbuh, dan berkembangnya suatu agen penyakit. Baik manusia, hewan, lingkungan (misalnya tanah dan air), hingga benda mati dapat berperan sebagai reservoir agen penyakit. Contoh reservoir yaitu monyet untuk virus zika dan tanah bagi bakteri Bacillus anthracis.

\section{Portal keluar}

Portal keluar adalah tempat atau lokasi agen infeksi meninggalkan reservoir atau inangnya. Misalnya virus influenza A dan bakteri Mycobacterium tuberculosis meninggalkan tubuh melalui saluran pernapasan (dengan cara bersin atau batuk), telur cacing melalui tinja, dan tungau Sarcoptes scabiei melalui luka kulit.

\section{Cara penularan}

Perpindahan agen infeksi berlangsung dengan berbagai cara. Secara garis besar, metode penularan ini terbagi dua, yaitu secara langsung dan tidak langsung (melalui perantara). Penularan langsung terjadi saat individu terinfeksi bertemu dengan individu sehat lalu melakukan kontak fisik (seperti bersentuhan kulit, berciuman, dan berhubungan seksual) atau berada dalam jarak dekat yang memungkinkan penularan secara aerosol (seperti bersin dan batuk) terjadi.

Walaupun individu terinfeksi dan individu sehat tidak berada di tempat yang sama, penularan dapat terjadi melalui suatu perantara. Perantara tersebut dapat berupa udara, benda mati (makanan, air, pakaian, atau kendaraan), maupun makhluk hidup yang digolongkan sebagai vektor (seperti nyamuk, lalat, dan caplak). Berdasarkan hal ini, suatu penyakit dapat digolongkan menjadi penyakit berperantara udara (airborne diseases), penyakit berperantara makanan (foodborne diseases), penyakit berperantara air (waterborne diseases), dan penyakit berperantara vektor (vector-borne diseases). 


\section{Portal masuk}

Portal masuk adalah tempat atau lokasi agen infeksi memasuki inang yang baru. Misalnya melalui virus rabies memasuki tubuh melalui luka pada kulit.

\section{Inang yang rentan}

Bagian terakhir dari rantai infeksi adalah inang yang rentan. Kerentanan ini dipengaruhi oleh beberapa hal, misalnya genetis dan status kekebalan tubuh.

\section{E. CONTOH PENYAKIT MENULAR}

Berikut beberapa contoh beserta gejalanya:

\section{Infeksi $\quad$ Saluran $\quad$ Pernapasan $\quad$ Akut}

(ISPA)

Infeksi pernapasan akut adalah infeksi yang mengenai saluran pernapasan dan dapat mengganggu fungsi pernapasan normal. ISPA dapat mempengaruhi saluran pernapasan atas (dari mulai hidung hingga bagian atas pita suara) atau pada saluran pernapasan bawah (dimulai dari bagian bawah pita suara dan berakhir di paru-paru). Anak-anak, orang lanjut usia, dan orang dengan gangguan sistem kekebalan tubuh lebih berisiko untuk terkena ISPA.

\section{Apa saja gejala infeksi pernapasan akut?}

Gejala-gejala ISPA yang dialami akan berbeda tergantung mengenai saluran pernapasan atas atau bawah. Gejala dapat termasuk:

1. Hidung tersumbat

2. Pilek

3. Batuk

4. Sakit tenggorokan

5. Sesak napas 
6. Bunyi nafas yang tidak normal

7. Sakit dada

8. Penurunan nafsu makan

9. Pegal-pegal

10. Kelelahan

\section{Diare}

Diare termasuk dalam 5 daftar penyakit menular. Diare ditandai dengan perubahan konsistensi tinja menjadi lebih encer dan berair atau meningkatnya frekuensi buang air besar. Diare umumnya dapat berlangsung beberapa hari dan sering kali membaik tanpa pengobatan khusus. Diare bisa bersifat akut atau kronis. Diare akut terjadi ketika kondisinya berlangsung selama kurang dari 14 hari, sedangkan diare kronis adalah diare yang terjadi lebih lama, yakni lebih dari 14 hari.

Diare akut dapat diakibatkan oleh infeksi virus, bakteri, dan parasit. Keluhan diare juga dapat timbul pada keracunan makanan. Bahkan ada suatu kondisi yang dikenal sebagai traveler's diarrhea, yaitu kondisi diare yang terjadi setelah terpapar bakteri atau parasit saat melakukan perjalanan ke negara berkembang atau daerah dengan sanitasi buruk. Diare kronis perlu dicurigai sebagai akibat dari penyakit atau kelainan usus, seperti penyakit celiac atau penyakit Crohn.

Dehidrasi dan diare Diare dapat menyebabkan seseorang kehilangan cairan dengan cepat dan berisiko mengalami dehidrasi. Jika pasien dengan dehidrasi tidak menerima penanganan maka dapat timbul komplikasi yang serius dan mengancam nyawa. Gejala-gejala dehidrasi meliputi kelelahan, bibir dan selaput lendir mulut tampak kering, peningkatan denyut jantung, sakit kepala, pusing, rasa haus meningkat, penurunan volume dan frekuensi buang air kecil. Penanganan diare terutama adalah melalui pemberian cairan pengganti (rehidrasi) baik melalui oral (minuman, larutan oralit) maupun melalui infus pada dehidrasi berat. 


\section{Tuberkulosis}

Tuberkulosis (TBC) adalah penyakit infeksi yang sangat menular yang terutama menyerang paruparu. Menurut Badan Organis Kesehatan Dunia/ World Health Organization (WHO), TBC adalah salah satu dari 10 penyebab utama kematian secara global, menewaskan sebanyak 1,7 juta orang pada tahun 2016. TBC merupakan penyakit yang dapat dicegah dan disembuhkan dengan pengobatan yang tepat.

$\begin{array}{llll}\text { Apa } & \text { saja } & \text { gejala }\end{array}$

Beberapa orang terinfeksi dengan bakteri Mycobacterium tuberculosis penyebab TBC tetapi tidak mengalami gejala. Kondisi ini dikenal sebagai TBC laten. TBC dapat menetap di dalam tubuh dalam keadaan tidak aktif selama bertahun-tahun, sebelum berkembang menjadi penyakit TBC aktif.

TBC aktif biasanya menimbulkan beberapa gejala. Gejala klinis TBC paru aktif adalah:

- Batuk >3 minggu

- Batuk berdahak atau batuk darah atau dahak (dahak)

- Berkeringat di malam hari

- Demam tanpa penyebab yang jelas

- Penurunan berat badan

- Rasa lelah yang tidak dapat dijelaskan

\section{Demam}

Berdarah

Demam berdarah adalah penyakit yang disebabkan oleh salah satu dari empat jenis virus Dengue yang ditularkan melalui gigitan nyamuk Aedes aegypti. Setelah terinfeksi salah satu jenis virus Dengue, tubuh Anda akan mengembangkan kekebalan terhadap virus jenis tersebut selama sisa hidup. Namun, Anda masih dapat terinfeksi dengan tiga jenis virus lainnya.

Gejala klinis demam berdarah adalah sebagai berikut:

- Demam selama 4-7 hari

- Sakit kepala

- Mual dan muntah 
- Sakit perut terutama di bagian ulu hati

- Sakit di bagian belakang bola mata

- Tanda perdarahan spontan, misalnya mimisan, bintik-bintik merah di kulit

\section{Difteri}

Difteri juga termasuk dalam 5 daftar penyakit menular. Difteri adalah infeksi bakteri berat yang menyebabkan pembentukan selaput lendir pada hidung dan tenggorokan. Bakteri penyebab difteri adalah Corynebacterium diphtheriae. Penularan bakteri ini adalah melalui kontak langsung dengan pasien difteri atau melalui kontak dengan benda-benda yang terkontaminasi bakteri, seperti cangkir atau tisu bekas pasien. Anda juga mungkin terkena difteri jika berada di sekitar orang yang terinfeksi difteri akibat menghirup droplet batuk atau bersin penderita.

Gejala difteri dapat timbul 2-5 hari setelah infeksi. Gejala yang muncul antara lain:

- Demam menggigil

- Sakit tenggorokan

- Suara serak

- Terbentuknya selaput tebal berwarna putih keabuan yang menutupi bagian amandel dan tenggorokan

- Pembesaran kelenjar getah bening terutama di daerah leher

- Sesak napas

- Rasa lelah berlebihan

Seseorang orang yang terinfeksi bakteri difteri dapat tidak menunjukkan gejala difteri atau hanya mengalami gejala yang menyerupai batuk pilek ringan, namun mereka tetap dapat menularkan infeksi bakteri difteri hingga enam minggu setelah infeksi awal.

Jika tidak segera diobati, difteri dapat menyebabkan kerusakan pada ginjal, sistem saraf, dan jantung. Kematian terjadi pada sekitar 3\% pasien difteri, terutama pasien anak-anak di bawah usia 15 tahun. Meskipun menyebar dengan mudah dari satu orang ke orang lain, difteri dapat dicegah melalui pemberian vaksin difteri. 


\section{F. CARA MENCEGAH}

Ketika seseorang batuk atau bersin akibat flu, semburan cairan bisa dengan mudah menyebar dan menempel selama 24 jam pada tempat-tempat yang biasa kita sentuh, seperti gagang pintu, telepon, pegangan di alat transportasi umum, dan benda-benda lain yang sering kali kita pegang. Ini membuat virus lebih mudah menempel di tangan. Jadi bersihkanlah tangan sesering mungkin secara menyeluruh, termasuk di bawah kuku dan di sela-sela jari.

Tidak hanya membersihkan tubuh, kita juga harus menjaga kebersihan alat makan dan pakaian. Jangan makan menggunakan alat makan dan minum seperti sendok-garpu, sedotan, piring, dan gelas yang sama dengan teman atau anggota keluarga yang sedang sakit. Begitu pula mengenakan pakaian si sakit. Cuci bersih alat makan dan pakaian anggota keluarga yang sakit agar penyakit tidak mudah menjalar.

\section{-Memakai}

Masker

Di tempat umum, kita bisa mencegah penyakit dengan memakai masker untuk menghindari diri dari menghirup bakteri dan virus. Tempat-tempat umum seperti pasar, terminal bus, stasiun, termasuk di kantor terancam penularan TBC.

Pengidap TBC yang buang ludah dan dahak sembarangan bisa membuat orang lain ikut tertular. Ludah dan dahak itu berisi bakteri TBC yang terbang ke udara setelah mengering. Bakteri yang terbang di udara ini bisa terhirup pernafasan orang di sekitar dan dengan cara itu penularan TBC umumnya berlangsung.

Dengan memakai masker, setidaknya kita sudah membentengi diri dari menghirup bakteri itu. Gunakan masker yang sesuai dan memenuhi standar kesehatan, bukannya masker gaya yang sekarang ini banyak dijual di pinggir jalan.

Ketika mengurus anggota keluarga yang sakit, kita juga disarankan memakai masker, apalagi bila penyakit yang diderita merupakan penyakit yang dapat menular lewat udara.

\section{-Vaksinasi}

Ada baiknya kita melakukan vaksinasi sebagai upaya pencegahan agar tidak terkena penyakit yang mudah menular. Saat ini berbagai penyakit sudah dapat dicegah dengan vaksin seperti 
pneumokokus, difteri, tetanus, pertusis, polio, influenza, hepatitis B, rotavirus, hingga kanker serviks. Terutama untuk anak-anak, jangan sampai mereka yang sehat menjadi rentan terserang penyakit.

\section{- Kurangi Kontak Langsung dengan Orang Sakit}

Bila teman atau anggota keluarga terserang penyakit yang mudah menular, kurangi risiko tertular dengan mengurangi kontak langsung dengan teman atau anggota keluarga yang sakit. Bila kita yang bertugas untuk mengurus si sakit, kenakan sarung tangan dan masker agar lebih aman.

\section{G. TENTANG COVID 19}

COVID-19 adalah penyakit menular yang disebabkan oleh jenis coronavirus yang baru ditemukan. Ini merupakan virus baru dan penyakit yang sebelumnya tidak dikenal sebelum terjadi wabah di Wuhan, Tiongkok, bulan Desember 2019.

Para ahli mengungkapkan sumber virus yang menyebabkan wabah SARS, MERS dan corona saat ini adalah berasal dari kelelawar, musang, dan unta. Hewan-hewan itu menjadi tempat inang virus sementara dari kelelawar ke manusia.

Pada kasus wabah virus corona 2019, laporan menyatakan sejumlah pasien yang terjangkit adalah para pekerja atau konsumen pasar hewan lokal yang menjual selain daging olahan juga hewan hidup seperti unggas, keledai, domba, babi, unta, rubah, musang, tikus bambu, landak, dan reptil.

Karena tidak pernah ada laporan yang menyebut virus corona menjangkiti hewan air, maka kemungkinan besar virus corona berasal dari hewan-hewan darat yang dijual di pasar hewan.

Peneliti kemudian menganalisis kode protein dari virus baru ini dan membandingkannya dengan kode protein dari virus corona yang ditemukan di berbagai inang hewan seperti burung, ular, marmut, landak, kelelawar, dan manusia. 
Ternyata mereka menemukan kode protein di 2019-nCoV (kode genetik virus corona) yang paling menyerupai kode genetik virus yang ada di ular.

Ular kerap memangsa kelelawar di alam liar.

Laporan juga menyatakan ular dijual di pasar makanan laut di Wuhan dan itu semakin menguatkan kemungkinan 2019-nCoV boleh jadi berpindah dari inangnya, yaitu kelelawar ke ular dan kemudian ke manusia ketika awal mulai virus ini merebak hingga menimbulkan kepanikan global karena mulai menyebar ke sejumlah negara, dari Prancis, Rusia hingga Amerika Serikat.

Dikutip dari laman the Telegraph, Minggu (26/1), berikut kronologi penyebaran virus Corona yang mulanya berasal dari Wuhan:

31 Desember 2019: Komisi Kesehatan Publik Wuhan melaporkan sebuah wabah penyakit mirip pneumonia merebak dengan 27 kasus dipastikan positif. Pemerintah kemudian mengungkap gejala awal virus ini sudah muncul sejak awal Desember, terutama di sekitar Pasar Makanan Laut Huanan, Wuhan.

9 Januari 2020: Ilmuwan mengidentifikasi sebuah virus baru sebagai penyebab wabah penyakit ini. Penularannya disebabkan virus corona jenis baru, mengingatkan orang akan wabah SARS yang menyebar dari China pada 2002. Virus corona bisa menulari baik hewan dan manusia, tapi jenis baru ini belum diidentifikasi menulari antar-manusia.

12 Januari 2020: Pemerintah mengumumkan kematian pria 61 tahun dari Wuhan yang terjangkit virus corona tiga hari sebelumnya.

13 Januari 2020: Kasus pertama di luar negeri tercatat di Thailand.

16 Januari 2020: Kasus serupa terjadi di Jepang, yang pertama di negara itu. 
20 Januari 2020: Virus corona menyebar. Dua pasien lagi terbukti positif di luar China, Korea Selatan dan Taiwan.

Sepekan setelah Badan Kesehatan Dunia (WHO) memperingatkan ada kemungkinan penularan bisa terjadi antar-manusia, ahli kesehatan di China membenarkan virus itu menyebar dari manusia ke manusia.

21 Januari 2020: Amerika Serikat mengumumkan kasus pertama, seorang pria berusia 30-an tahun dari Negara Bagian Washington, yang baru pulang dari Wuhan.

22 Januari 2020: China mengatakan virus ini mampu beradaptasi dan bermutasi. Orang asing kedua terinfeksi di China--seorang warga Thailand. Kini ada empat kasus di Thailand.

23 Januari 2020: China mengumumkan tiga kota dikarantina, sekitar 20 juta warga dilarang keluar.

25 Januari: Dokter Liang Wudong (62) yang bertugas di Rumah Sakit Hubei Xinhua Wuhan, juga dikabarkan meninggal dunia karena vrus corona. Informasi itu disampaikan lewat pemberitaan stasiun televisi China Global Television Network.

Pemerintah Malaysia mengumumkan empat orang dipastikan terinfeksi virus corona.

26 Januari: 56 orang meninggal di China karena virus corona. Lebih dari 2000 lainnya terinfeksi

Kasus COVID-19 di Indonesia diawali dari sebuah pesta dansa di Klub Paloma \& Amigos, Jakarta. Peserta acara tersebut bukan hanya warga negara Indonesia saja, tetapi juga multinasional, termasuk warga Jepang yang menetap di Malaysia. Berikut kronologi virus corona yang muncul di Depok, Jawa Barat, Indonesia.

Kasus pertama, NT (31) 
- 14 Februari: NT mengikuti acara pesta dansa dengan peserta multinasional, termasuk Jepang. Ketika kembali ke domisilinya (Malaysia), warga negara Jepang tersebut positif mengidap COVID-19.

- 16 Februari: Selang dua hari setelah itu, NT mengalami batuk, sesak, dan demam selama kurun waktu 10 hari.

- 26 Februari: Untuk mengatasi keluhannya NT berobat ke RS Mitra Depok. Di sana dokter mendiagnosis NT mengidap Bronkopneumonia, salah satu jenis pneumonia yang menyebabkan peradangan pada paru-paru. NT ditetapkan sebagai suspect virus corona Wuhan, dengan riwayat kontak kasus positif COVID-19.

- 29 Februari: NT dirujuk ke Rumah Sakit Penyakit Infeksi (RSPI) Sulianti Saroso, meski keadaanya sudah membaik (tidak demam, masih batuk).

1 Maret: Dokter mengambil spesimen berupa nasofaring, orofaring, serum, dan sputum. Sampel ini, kemudian dikirim ke Badan Penelitian dan Pengembangan Kesehatan (Litbangkes). Pengambilan Bronchoalveolar lavage (BAL) akan dikirim kemudian. Kasus yang dialami NT masuk dalam kategori pengawasan.

\section{Kasus kedua, MD (64)}

- 20 Februari: MD berkontak dengan anaknya NT yang diduga mengidap COVID-19.

- 22 Februari: Dua hari setelahnya, MD menunjukkan gejala infeksi virus corona. Ia juga berobat ke RS Mitra Depok dengan dengan diagnosis tifoid dan Infeksi Saluran Pernapasan Akut (ISPA). MD diduga mengidap COVID-19.

- 29 Februari: Beserta anaknya NT, mereka dirujuk ke RSPI Sulianti Saroso.

- 1 Maret: Prosedurnya sama dengan NT, dokter mengambil spesimen berupa nasofaring, orofaring, serum, dan sputum. Sampel ini kemudian dikirim ke Litbangkes. Kasus MD masuk dalam kategori pengawasan.

Pada Senin, 2 Maret 2020, Presiden Jokowi Widodo mengatakan kedua positif mengidap virus corona wuhan atau COVID-19. 
Menurut beberapa media massa, kronologi virus corona Wuhan, tatalaksana kasus, pengobatan, pengambilan, hingga pengiriman spesimen di atas, diperoleh dari petugas Surveilans Kota Depok.

\section{Dinkes Isolasi Rumah}

Kasus pertama COVID-19 di Indonesia ini, didapat melalui penelusuran Kementerian Kesehatan RI. "Orang Jepang ke Indonesia bertemu siapa, ditelusuri dan ketemu. Ternyata, orang yang terkena virus corona berhubungan dengan dua orang, ibu 64 tahun dan putrinya 31 tahun," kata Jokowi

Penanganan kasus pertama virus corona Wuhan tak hanya berfokus pada kedua pengidapnya. Demi penularan lebih jauh, pemerintah juga mengisolasi rumah pengidap COVID-19 di kota Depok.

Menteri Kesehatan Terawan Agus Putranto mengatakan, rumah warga Depok yang positif mengidap virus corona telah diisolasi,

"Sesuai prosedur, Dinas Kesehatan (Dinkes) setempat langsung melakukan pemantauan, juga melakukan isolasi rumah dan sebagainya," jelasnya.

\section{Apa Kabar NT dan MD?}

Coba tebak, berapa banyaknya jumlah korban tewas akibat serangan virus korona Wuhan? Menurut data The GISAID, setidaknya 3.044 meninggal dunia akibat virus misterius ini. Lalu, bagaimana dengan warga Depok yang positif mengidap COVID-19?

Menurut Direktur RSPI Sulianti Saroso, Mohammad Syahril, baik NT maupun MD dalam keadaan baik. Kondis keduanya sadar penuh, tidak ada keluhan panas, tidak sesak napas, dan gejala batuknya pun juga berkurang.

Di samping itu, tanda vital dari keduanya juga dalam keadaan normal. Mulai dari tensi darah, suhu, pernapasan, dan nadi.

Bagaimana denganmu? Bila kamu mencurigai diri atau anggota keluarga mengidap infeksi virus corona atau sulit membedakan gejala COVID-19 dengan flu, segeralah tanyakan pada dokter. 
Kamu bisa kok bertanya langsung pada_dokter melalui aplikasi Halodoc. Dengan begitu, kamu tidak perlu ke rumah sakit dan meminimalkan risiko terjangkit berbagai virus dan penyakit.

\section{Bagaimana Respon Pemerintah?}

COVID-19 bukanlah penyakit global pertama kali yang dihadapi Indonesia. Jauh sebelumnya, tepatnya pada 2003 pemerintah Indonesia juga pernah berhadapan dengan penyakit Severe Acute

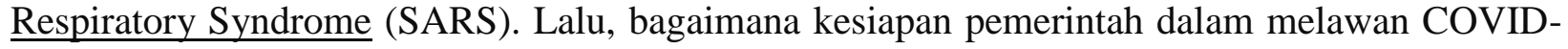
19 ?

Presiden Jokowi mengatakan, pemerintah Indonesia memiliki kesiapan dan perlengkapan yang memadai untuk menangani kasus virus corona pertama ini. Tak cuma itu, pemerintah juga berupaya untuk menekan penyebaran virus korona Wuhan, yang kini vaksinnya belum ditemui.

Menurut Jokowi, kini pemerintah telah menyiapkan lebih dari 100 rumah sakit dengan ruang isolasi untuk menangani COVID-19. Disamping itu, pemerintah Indonesia juga memiliki peralatan medis yang memadai sesuai standar internasional.

Selain tim medis, Jokowi juga membentuk tim lain untuk mengatasi virus corona Wuhan. Tim ini merupakan gabungan dari TNI-Polri serta sipil untuk melakukan penanganan di lapangan.

Singkat kata, pemerintah siap dan menjamin ketersedian anggaran mengatasi serangan virus corona. Mulai dari pengobatan, penanganan, dan pencegahannya agar tak menyebar. 


\section{BAB 3}

\section{KESIMPULAN}

Definisi penyakit menular adalah gangguan yang disebabkan oleh organisme seperti bakteri, virus, jamur, atau parasit. Disamping itu juga ada banyak organisme yang ada di dalam tubuh yang bersifat membantu kekebalan tubuh, namun dalam kondisi tertentu, beberapa organisme menyebabkan penyakit.

Ketika seseorang batuk atau bersin akibat flu, semburan cairan bisa dengan mudah menyebar dan menempel selama 24 jam pada tempat-tempat yang biasa kita sentuh, seperti gagang pintu, telepon, pegangan di alat transportasi umum, dan benda-benda lain yang sering kali kita pegang. Ini membuat virus lebih mudah menempel di tangan. Jadi bersihkanlah tangan sesering mungkin secara menyeluruh, termasuk di bawah kuku dan di sela-sela jari.

Tidak hanya membersihkan tubuh, kita juga harus menjaga kebersihan alat makan dan pakaian. Jangan makan menggunakan alat makan dan minum seperti sendok-garpu, sedotan, piring, dan gelas yang sama dengan teman atau anggota keluarga yang sedang sakit. Begitu pula mengenakan pakaian si sakit. Cuci bersih alat makan dan pakaian anggota keluarga yang sakit agar penyakit tidak mudah menjalar.

Pencegahan juga bisa dilakukan dengan memakai masker, vaksinisasi, dan tidak berdekatan dengan orang yang sakit. 


\section{DAFTAR PUSTAKA}

https://www.halodoc.com/kronologi-lengkap-virus-corona-masuk-indonesia

https://www.merdeka.com/dunia/dari-pasar-hewan-hingga-kepanikan-global-kronologi-penyebaranvirus-corona-china.html

https://www.kompas.com/skola/read/2020/03/02/143000069/apa-itu-penyakit-menular-?page=all

https://www.alodokter.com/penyakit-menular-yang-umum-di-indonesia

https://id.wikipedia.org/wiki/Penyakit menular

https://www.ciputrahospital.com/5-daftar-penyakit-menular-yang-sering-dialami-orang-indonesia/ 